\title{
ECOEPIDEMIOLOGÍA DE LOS VIRUS DE INFLUENZA AVIAR
}

\author{
BELDOMENICO, P. M. ${ }^{1}$ \& UHART, M. M. ${ }^{1}$
}

\begin{abstract}
RESUMEN
Luego del surgimiento y posterior propagación del virus de influenza aviar de alta patogenicidad H5N1 en Asia, el número de publicaciones científicas sobre influenza aviar se ha incrementado considerablemente. Sin embargo, son escasos los trabajos de revisión que intenten recopilar el conocimiento actual para describir la historia natural de estos virus. El presente trabajo revisa lo que hasta hoy sabemos de la ecoepidemiología de los virus de influenza aviar. Se describen los tipos de virus de influenza aviar de alta y baja patogenicidad, los reservorios naturales, la importancia de los humedales y las especies animales puente, la transmisión y la relación de las aves silvestres con las aves domésticas, las posibles rutas de transporte del virus ya sea por las mismas aves migratorias o por acciones del ser humano y el comercio internacional. Se reseñan los recientes brotes en aves domésticas y se analizan las razones por las cuales es poco probable que ocurra la transmisión por aves migratorias desde América del Norte hacia América del Sur del virus de alta patogenicidad H5N1. Se recomiendan las condiciones básicas de manejo y bioseguridad en explotaciones industriales y domésticas de aves de granja para evitar la difusión de este virus. Se señala que el limitado conocimiento sobre la ecoepidemiología de este virus requiere estudios de cooperación internacional e interinstitucional para implementar medidas de alerta temprana y prevención en caso de que el virus H5N1 pudiera ser introducido en Sudamérica.
\end{abstract}

\section{SUMMARY}

\section{Ecoepidemiology of avian influenza viruses.}

Following the emergence and ulterior propagation of highly pathogenic avian influenza H5N1 in Asia, the amount of scientific literature on avian influenza has increased considerably. However, review articles that intend to collate the current knowledge to describe the natural history of these viruses are scarce. The present work reviews our present knowledge on the ecoepidemiology of influenza viruses. A description is offered of the types of avian influenza viruses, highly and low pathogenic, their natural reservoirs, the importance of wetlands and bridge species, the transmission and the relationship between wild birds and poultry, the plausible ways of propagation of the virus,

1.Global Health Programs. Wildlife Conservation Society. Global Avian Influenza Network for Surveillance. Emails: pbeldomenico@wcs.org; muhart@wcs.org Manuscrito recibido el 3 de marzo de 2008 y aceptado para su publicación el 27 de mayo de 2008. 
either by migratory birds or by human actions and international commerce. Recent outbreaks in poultry are reviewed and the reasons why migratory birds are unlikely to carry the highly pathogenic H5N1 virus to South America, should it enter North America, are discussed. Management and biosafety measures to avoid the propagation in the virus are recommended for poultry farming and industry. It is highlighted that the limited knowledge on the ecoepidemiology of this virus requires international and interinstitutional cooperation to implement early warning systems and prevention in the case highly pathogenic H5N1 is introduced in South America. 